\title{
Impact of obesity on functional and oncological outcomes in radical perineal prostatectomy
}

\author{
Bulent Altay, MD; Bulent Erkurt, MD; Vahit Guzelburc, MD; Murat Can Kiremit, MD; Mustafa Yucel Boz, MD; \\ Selami Albayrak, MD
}

Department of Urology, Istanbul Medipol University, Istanbul, Turkey

Cite as: Can Urol Assoc J 2015;9(11-12):E766-9. http://dx.doi.org/10.5489/cuaj.3094 Published online November 4, 2015.

\section{Abstract}

Introduction: We evaluated the impact of obesity on perioperative morbidity, functional, and oncological outcomes after radical perineal prostatectomy (RPP).

Methods: A total of 298 consecutive patients underwent RPP at our institution. Patients were categorized into 3 groups based on their body mass index (BMI): Normal weight $<25 \mathrm{~kg} / \mathrm{m}^{2}$ (Group 1 ), overweight 25 to $<30 \mathrm{~kg} / \mathrm{m}^{2}$ (Group 2), and obese $\geq 30 \mathrm{~kg} / \mathrm{m}^{2}$ (Group 3). We compared the groups with respect to perioperative data, postoperative oncologic, and functional outcomes. Evaluation of urinary continence and erectile function was performed using a patient-reported questionnaire and the International Index of Erectile Function-5 questionnaire, respectively, administered preoperatively and at 3, 6, and 12 months. Limitations included short follow-up time, retrospective design and lack of a morbidly obese group.

Results: No significant differences were found among the 3 groups with regard to operative time, estimated blood loss, length of hospital stay, catheter removal time, positive surgical margin, and complication rates. At 12 months, 94.7\%, 95\% and 95\% of normal, overweight and obese patients, respectively, were continent (free of pad use) ( $p=0.81)$. At 12 months, 30.6\%, 29.8\% and $30.4 \%$ of patients had spontaneous erections and were able to penetrate and complete intercourse in Group 1, Group 2, and Group 3, respectively ( $p=0.63$ ).

Conclusions: In this cohort of patients, no clinically relevant risks were associated with increasing BMI.

\section{Introduction}

Currently more than $30 \%$ of the adult population in the United States are obese, as per the World Health Organization criteria. ${ }^{1}$ Obesity is an independent risk factor for increased risk of biochemical recurrence (BCR), positive surgical margin
(PSM) and worse functional outcomes after radical retropubic prostatectomy (RRP). ${ }^{2-5}$ Similar studies have also shown increased complication rates and lower recovery of continence and potency after laparoscopic radical prostatectomy (LRP). ${ }^{6-8}$ Furthermore, large series have shown that obesity is associated with greater estimated blood loss (EBL), longer operative duration, and hospital stay after robotic laparoscopic radical prostatectomy (RLRP). ${ }^{9-11}$ Literature evaluating the limitations of radical perineal prostatectomy (RPP) in obese men is limited. ${ }^{12-15}$

We have analyzed our RPP outcomes stratified by body mass index (BMI) categories to determine the perioperative morbidity, oncologic and functional outcomes in overweight and obese men compared with a normal-weight cohort.

\section{Methods}

With Institutional Review Board approval, we retrospectively analyzed 298 men who had undergone RPP from 2006 April to 2013 December using our previously described technique. ${ }^{16}$ High-risk patients (Gleson score $>7$ or $4+3$, prostate-specific antigen (PSA) $>10$ and clinical stage $\geq T 3$ ) were excluded due to the impossibility to carry out an extended lymphadenectomy. Bilateral or unilateral nervesparing surgery was performed in all potent men. All patients were encouraged to use oral phosphodiesterase- 5 inhibitors after surgery (tadalafil, $20 \mathrm{mg}$ twice weekly or $5 \mathrm{mg}$ daily). Preoperative variables, including age, PSA, transrectal ultrasound volume, stage, biopsy Gleason score and BMI were reviewed. We excluded patients who had been followed up for less than 12 months, who had received external beam radiotherapy or androgen suppression, and patients with a history of transurethral resection of the prostate.

Patients were divided into 3 groups according to the BMI: normal weight $<25 \mathrm{~kg} / \mathrm{m}^{2}$ (Group 1), overweight $25-29.9 \mathrm{~kg} / \mathrm{m}^{2}$ (Group 2), and obese $\geq 30 \mathrm{~kg} / \mathrm{m}^{2}$ (Group $3)$. Perioperative variables, including operative time, EBL, 
hospital stay, catheterization time, PSM and complications were analyzed. PSA, urinary continence, erectile function and late complications were evaluated at postoperative 3, 6, and 12 months. BCR was defined as PSA levels of $\geq 0.2 \mathrm{ng} /$ $\mathrm{mL}$. A single question from the urinary domain of Expanded Prostatic Index Composite (EPIC) questionnaire (question 5) was used to evaluate the urinary continence: "How many pads or adult diapers per day did you usually use to control urinary leakage during the last 4 weeks?"17 Patients were considered continent if they did not use even a security pad. Erectile function was evaluated using the International Index of Erectile Function (IIEF-5) questionnaire. Patients were considered potent if they were able to achieve and maintain an erection that allowed intercourse with or without the use of oral phosphodiesterase-5 inhibitors.

All data were presented as a mean \pm standard deviation for continuous variables and as percentages for categorical variables. The Kolmogorov-Smirnov test was used to verify normal distributions. Analysis of variance or Kruskal-Wallis and Mann-Whitney $U$ tests were performed according to the results of the Kolmogorov-Smirnov normality test to determine whether the differences were statistically significant. Chi-square test or Fisher's exact test was used to compare categorical variables. Statistical analysis was performed using the SPSS 15.0 (SPSS Inc., Chicago, IL) statistical software package. A $p$ value of less than 0.05 was considered statistically significant.

\section{Results}

The clinical stage distribution was $\mathrm{T} 1 \mathrm{c}, \mathrm{T} 2 \mathrm{a}$ and $\mathrm{T} 2 \mathrm{~b}$ in $87 \%, 8 \%$ and, $5 \%$ of cases, respectively. The percentage of the patients with biopsy Gleason sum $<7$, and $3+4$ was $67.5 \%$, and $32.5 \%$, respectively. Patients with greater BMI were older $(p=0.04)$ and had a higher biopsy Gleason sum $(p=0.03)$. Otherwise, there were no statistically significant differences among the 3 groups in total PSA, prostate volume, and TNM stage (Table 1).

No significant association was noted between BMI and nerve-sparing status $(p=0.27)$. The 3 groups were statistically similar in terms of operative time, hospital stay, EBL, and catheterization time (Table 2).

Based on the Clavien-Dindo classification of adverse events, 11,11 and 8 patients $(9.5 \%, 10.7 \%$ and $9.8 \%)$ had grade I complications, while 9,7 and 6 patients $(7.8 \%, 6.8 \%$ and $7.4 \%$ ) had grade II complications, 3, 3 and 2 patients $(2.6 \%, 2.9 \%, 2.4 \%)$ had grade III-a, 1,1 and 0 patients $(0.8 \%, 0.9 \%, 0 \%)$ had grade III-b complications in normal weight, overweight and obese men, respectively. Only 1 patient $(1.2 \%)$ had a grade IV complication in Group 3. The complication rates among the 3 groups were similar $(p=0.97)$. Rectal injury was experienced in 1 patient in Group 1. No blood transfusions were required. Anastomotic strictures were observed in $2(1.7 \%), 2(1.9 \%)$ and $1(1.2 \%)$ patients in Group 1, Group 2, and Group 3, respectively $(p=0.94)$. Wound complications were recorded as infection (superficial/deep) and bleeding. The rate of postoperative superficial wound infection was higher in obese patients (4 patients [4.9\%] in Group 3 and none [ $p=0.03$ ] in other groups).

The overall incidence of PSM was $6.3 \%(n=19)$; of these, $31.5 \%(n=6)$ were peripheral, $10.5 \%(n=2)$ were apical, and $57.8 \%(n=11)$ were prostate base. No significant differences were found in both the rate and location of PSM between groups. The overall incidence of BCR was $2.6 \%$ $(\mathrm{n}=8)$. The incidence of PSM and BCR were not related to BMI (Table 3).

Continence rates were similar among the 3 groups at the time of catheter removal and at 3-, 6- and 12-month followup. Of the 224 patients $(75.1 \%)$ who were potent preoperatively, $89(39.7 \%)$ were able to obtain erections adequate for intercourse at the 12-month follow-up. At 12 months after

\section{Table 1. Preoperative baseline patient characteristics}

\begin{tabular}{|c|c|c|c|c|}
\hline Variables & $\begin{array}{c}\text { Group } 1 \\
\text { (BMI }<25 \mathrm{~kg} / \mathrm{m}^{2} \text { ) } \\
\mathrm{n}=115\end{array}$ & $\begin{array}{c}\text { Group } 2 \\
\text { (BMI } 25 \text { to }<30 \mathrm{~kg} / \mathrm{m}^{2} \text { ) } \\
n=102\end{array}$ & $\begin{array}{c}\text { Group 3 } \\
\begin{array}{c}(B M I \\
\left.\geq \mathbf{3 0} \mathrm{kg} / \mathrm{m}^{2}\right) \\
\mathbf{n}=\mathbf{8 1}\end{array}\end{array}$ & $p$ value \\
\hline Age (y) & $56.8 \pm 6.8$ & $60.7 \pm 7.3$ & $66.2 \pm 6.2$ & 0.04 \\
\hline BMI $\left(\mathrm{kg} / \mathrm{m}^{2}\right)$ & $20.9 \pm 3.9$ & $27.5 \pm 2.8$ & $34.1 \pm 3.1$ & 0.01 \\
\hline PSA (ng/mL) & $6.8 \pm 3.4$ & $6.9 \pm 4.1$ & $7.1 \pm 3.8$ & 0.36 \\
\hline Prostate volume $(\mathrm{mL})$ & $38.8 \pm 18.1$ & $40.1 \pm 17.9$ & $39.2 \pm 17.7$ & 0.41 \\
\hline \multicolumn{5}{|l|}{ Clinical stage $(\mathrm{n})$} \\
\hline $\mathrm{T} 1 \mathrm{c}$ & $99(86 \%)$ & $89(87.2 \%)$ & $71(87.6 \%)$ & 0.61 \\
\hline $\mathrm{T} 2 \mathrm{a}$ & $10(8.6 \%)$ & $8(7.8 \%)$ & $6(7.4 \%)$ & 0.56 \\
\hline $\mathrm{T} 2 \mathrm{~b}$ & $6(5.2 \%)$ & $5(4.9 \%)$ & $4(4.9 \%)$ & 0.32 \\
\hline \multicolumn{5}{|l|}{ Biopsy Gleason sum ( $\mathrm{n}$ ) } \\
\hline$<7$ & $80(69.5 \%)$ & $72(70.5 \%)$ & $49(60.4 \%)$ & 0.08 \\
\hline $3+4$ & 35 (30.4\%) & $30(29.4 \%)$ & $32(39.5 \%)$ & 0.03 \\
\hline
\end{tabular}


Altay et al.

\begin{tabular}{|c|c|c|c|c|}
\hline Variables & $\begin{array}{c}\text { Group1 } \\
\left(\mathrm{BMI}<25 \mathrm{~kg} / \mathrm{m}^{2}\right)\end{array}$ & $\begin{array}{c}\text { Group } 2 \\
\text { (BMI } 25 \text { to }<30 \mathrm{~kg} / \mathrm{m}^{2} \text { ) }\end{array}$ & $\begin{array}{c}\text { Group 3 } \\
\left(\mathrm{BMI} \geq \mathbf{3 0} \mathrm{kg} / \mathrm{m}^{2}\right)\end{array}$ & $p$ value \\
\hline Operative time (min) & $118.7 \pm 38.1$ & $116.5 \pm 40.3$ & $121.3 \pm 32.4$ & 0.48 \\
\hline Hospital stay (days) & $2 \pm 0.5$ & $2 \pm 0.4$ & $2 \pm 0.5$ & 0.96 \\
\hline $\mathrm{EBL}(\mathrm{mL})$ & $289.9 \pm 86.1$ & $293.1 \pm 98.7$ & $299.2 \pm 88.4$ & 0.91 \\
\hline Catheterization time (days) & $10.2 \pm 1.2$ & $10.1 \pm 1.9$ & $10.8 \pm 1.7$ & 0.98 \\
\hline \multicolumn{5}{|l|}{ Nerve sparing status } \\
\hline Bilateral & $42(36.5 \%)$ & $38(37.2 \%)$ & $31(38.2 \%)$ & 0.76 \\
\hline Unilateral & $33(28.6 \%)$ & $28(27.4 \%)$ & $25(30.8 \%)$ & 0.68 \\
\hline Non-nerve sparing & $40(34.7 \%)$ & $36(35.2 \%)$ & $25(30.8 \%)$ & 0.89 \\
\hline
\end{tabular}

RPP, $29.5 \%(n=34), 28.4 \%(n=29)$ and $27.1 \%(n=22)$ of Group 1, Group 2 and Group 3 patients, respectively, reported sufficient erections $(p=0.63)$. Postoperative erectile function at least 1 year after RPP was unaffected by BMI.

\section{Discussion}

Obesity has been reported to be a risk factor for developing PCa, adverse pathological features and higher BCR rates after RP. ${ }^{18,19}$ It has also been shown that increasing $\mathrm{BMI}$ is correlated with increased $\mathrm{EBL}$ and operative time in RP. ${ }^{20}$ Our results revealed that obesity is not associated with worse functional and oncological outcomes in men who underwent RPP. We noted higher biopsy Gleason sums and higher mean age for the obese group, which is in accordance with previous RP series of obese men. ${ }^{21}$

Only a few small studies have provided data for obese patients who underwent RPP. Dahm and colleagues have reported an acceptable mean operative time (188 min), EBL $(573 \mathrm{~mL})$ and PSM rate $(27.8 \%)$ in their series of 18 morbidly obese patients. ${ }^{13}$ Boczko and colleagues analyzed only 7 obese patients (BMI $>30 \mathrm{~kg} / \mathrm{m}^{2}$ ) who underwent RPP and reported comparable perioperative outcomes, with a PSM rate of $28.5 \% .{ }^{12}$ Fitzsimons and colleagues have reported that both RPP and RRP were associated with similarly increased risk of increased PSM rate and EBL among obese men. ${ }^{14}$ Yang and colleagues found no significant associations between increased BMI and EBL and PSM rates. Whereas, a significant increased complication rate in the obese group ( $16.9 \%$ vs $7 \%, p=0.03$ ) has been reported..$^{15}$ To our knowledge, our study is the first to compare oncological (PSM and BCR rates) and functional outcomes (continence and erectile function) between obese and non-obese men undergoing RPP.

In our series the overall continence rates at both catheter removal times (88.2\%) and at 12 months (94.9\%) were higher when compared with the results of large RRP, RLP and RLRP series. ${ }^{3,6,11}$ In contrast to the published data of other non-perineal RP series, we also found that continence rates were similar when compared with non-obese patients despite the fact that obese group was about 10 years older. The perineal approach provides good visualization to the both external urinary sphincter and prostatic urethra just proximal to the sphincter. Therefore, the possibility for damage to the external sphincter during both dissection and anastomosis is minimal, independent of age and BMI.

In our series, continence rates were unaffected by increasing BMI and age after RPP. To the best of our knowledge,

\begin{tabular}{|c|c|c|c|c|}
\hline Variables & $\begin{array}{c}\text { Group1 } \\
\left(\mathrm{BMI}<25 \mathrm{~kg} / \mathrm{m}^{2}\right)\end{array}$ & $\begin{array}{c}\text { Group } 2 \\
(B M I) 25 \text { to }<30 \mathrm{~kg} / \mathrm{m}^{2} \text { ) }\end{array}$ & $\begin{array}{c}\text { Group 3 } \\
\left(B M I \geq \mathbf{3 0} \mathbf{~ k g} / \mathrm{m}^{2}\right)\end{array}$ & $p$ value \\
\hline PSM (n) & $8(6.9 \%)$ & $6(5.8 \%)$ & $5(6.1 \%)$ & 0.68 \\
\hline $\mathrm{BCR}(\mathrm{n})$ & $3(2.6 \%)$ & $3(2.9 \%)$ & $2(2.4 \%)$ & 0.24 \\
\hline \multicolumn{5}{|l|}{ Continence $(\mathrm{n})$} \\
\hline At catheter removal & $102(88.6 \%)$ & $89(87.2 \%)$ & $72(88.8 \%)$ & 0.92 \\
\hline 3 months & $103(89.5 \%)$ & $89(87.2 \%)$ & $72(88.8 \%)$ & 0.89 \\
\hline 6 months & $103(89.5 \%)$ & $90(88.2 \%)$ & $74(91.3 \%)$ & 0.88 \\
\hline 12 months & $109(94.7 \%)$ & 97 (95\%) & 77 (95\%) & 0.81 \\
\hline \multicolumn{5}{|l|}{ Mean IIEF-5 } \\
\hline 3 months & $9.1 \pm 3.1$ & $8.9 \pm 4.4$ & $8.7 \pm 3.8$ & 0.32 \\
\hline 6 months & $9.8 \pm 6.2$ & $9.1 \pm 7.9$ & $9.5 \pm 8.5$ & 0.28 \\
\hline 12 months & $13.8 \pm 5.4$ & $13.1 \pm 4.8$ & $12.8 \pm 3.7$ & 0.26 \\
\hline
\end{tabular}


no study exists evaluating the effect of obesity on the erectile function in men underwent RPP. Similar to the continence parameter, we found that obesity was not a risk factor for recovery of erectile function in obese men who underwent RPP despite their older age. The heterogeneity in the prevalence of metabolic disorders (diabetes, hypercholesterolemia, smoking) or the rate of regular tadalafil usage postoperatively between groups can explain the similar potency rates despire the age difference.

The limitations of the present study are short follow-up time, retrospective design and lack of a morbidly obese group. Shorter hospital stays and lower blood loss with more rapid recovery compared to RRP are the advantages of RPP, similar to those attributed to RLP or RALP.

\section{Conclusion}

Our results revealed that being overweight is not a risk factor in RPP patients, in contrast to published data of non-perineal radical prostatectomy techniques. Obese men tend to have a thick abdominal wall, more pelvic and intraperitoneal fat tissue and a deep pelvis which could increase the surgical difficulties of RRP or LRP in favour of perineal surgery. In our experience, the amount of perineal fat tissue was not correlated with BMI. Additionally, perivesical fat tissue was not a disadvatage in the perineal approach. Therefore, increased BMI is not a handicap for dissection in perineal surgery. RPP provides a nearly perfect preservation of the external urinary sphincter and the bladder neck circular fibers. Therefore, RPP should be considered safe and efficient for obese patients.

Competing interests: The authors declare no competing financial or personal interests.

This paper has been peer-reviewed.

\section{References}

1. Flegal KM, Carrol MD, Ogden CL, et al. Prevalence and trends in obesity among US adults, 1999-2008. JAMA 2010;303:235-41. http://dx.doi.org/10.1001/jama.2009.2014

2. Jayachandran J, Aronson WJ, Terris MK, et al. Obesity and positive surgical margins by anatomic location after radical prostatectomy: Results from the Shared Equal Access Regional Cancer Hospital database. BJU Int 2008;102:964-8. http://dx.doi.org/10.1111/i.1464-410X.2008.07881.x
3. Hsu El, Hong EK, Lepor H. Influence of body weight and prostate volume on intraoperative, perioperative, and postoperative outcomes after radical retropubic prostatectomy. Urology 2003;61:601-6. http:// dx.doi.org/10.1016/S0090-4295(02)02422-6

4. Freedland SJ, Grubb KA, Yiu SK, et al. Obesity and capsular incision at the time of open retropubic radical prostatectomy. J Urol 2005;174:1798-801. http://dx.doi.org/10.1097/01.ju.0000177077.53037.72

5. Amling $\mathrm{CL}$, Riffenburgh $\mathrm{RH}$, Sun $\mathrm{L}$, et al. Pathologic variables and recurrence rates as related to obesity and race in men with prostate cancer undergoing radical prostatectomy. J Clin Oncol 2004;22:439-45. http://dx.doi.org/10.1200/JC0.2004.03.132

6. Campeggi A, Xylinas E, Ploussard G, et al. Impact of body mass index on perioperative morbidity, oncological, and functional outcomes after extraperitoneal laparoscopic radical prostatectomy. Urology 2012;80:576-84. http://dx.doi.org/10.1016/i.urology.2012.04.066

7. El-Feel A, Davis JW, Deger $\mathrm{S}$, et al. Laparoscopic radical prostatectomy-an analysis of factors affecting operating time. Urology 2003;62:314-8. http://dx.doi.org/10.1016/S0090-4295(03)00250-4

8. Bhayani SB, Pavlovich CP, Strup SE, et al. Laparoscopic radical prostatectomy: A multi-institutional study of conversion to open surgery. Urology 2004;63:99-102. http://dx.doi.org/10.1016/i.urology.2003.08.018

9. Ahlering TE, Eichel L, Edwards R, et al. Impact of obesity on clinical outcomes in robotic prostatectomy. Urology 2005;65:740-4. http://dx.doi.org/10.1016/i.urology.2004.10.061

10. Castle EP, Atug F, Woods $M$, et al. Impact of body mass index on outcomes after robot assisted radical prostatectomy. World J Urol 2008;26:91-5. http://dx.doi.org/10.1007/s00345-007-0217-0

11. Herman MP, Raman JD, Dong $S$, et al. Increasing body mass index negatively impacts outcomes following robotic radical prostatectomy. JSLS 2007;11:438-42.

12. Boczko J, Melman A. Radical perineal prostatectomy in obese patients. Urology 2003;62:467-9. http:// dx.doi.org/10.1016/S0090-4295(03)00464-3

13. Dahm P, Yang BK, Salmen CR, et al. Radical perineal prostatectomy for the treatment of localized prostate cancer in morbidly obese patients. J Urol 2005;174:131-4. http://dx.doi.org/10.1097/01. ju.0000161593.29525.e2

14. Fitzsimons NJ, Sun LL, Dahm P, et al. A single-institution comparison between radical perineal and radical retropubic prostatectomy on perioperative and pathological outcomes for obese men: An analysis of the Duke Prostate Center database. Urology 2007;70:1146-51. http://dx.doi.org/10.1016/i. urology.2007.07.065

15. Yang BK, Gan TJ, Salmen CR, et al. Radical perineal prostatectomy for treatment of localized prostate cancer in obese and nonobese patients: a matched control study. Urology 2006;67:990-5. http://dx.doi. org/10.1016/i.urology.2005.11.046

16. Albayrak $S$, Canguven 0 , Goktas $C$, et al. Radical perineal prostatectomy and early continence: Outcomes after 120 cases. Int Braz J Urol 2010;36:693-9. http://dx.doi.org/10.1590/S167755382010000600007

17. Wei JT, Dunn RL, Litwin MS, et al. Development and validation of the expanded prostate cancer index composite (EPIC) for comprehensive assessment of health-related quality of life in men with prostate cancer. Urology 2000;56:899-905. http://dx.doi.org/10.1016/S0090-4295(00)00858-X

18. Giovannucci E, Rimm EB, Liu Y, et al. Body mass index and risk of prostate cancer in U.S. health professionals. J Natl Cancer Inst 2003;95:1240-4. http://dx.doi.org/10.1093/inci/dig009

19. Kane CJ, Bassett WW, Sadetsky N, et al. Obesity and prostate cancer clinical risk factors at presentation: Data from CaPSURE. J Urol 2005;173:732-6. http://dx.doi.org/10.1097/01.ju.0000152408.25738.23

20. Chang SS, Duong DT, Wells N, et al. Predicting blood loss and transfusion requirements during radical prostatectomy: The significant negative impact of increasing body mass index. J Urol 2004;171:1861-5. http://dx.doi.org/10.1097/01.ju.0000120441.96995.e3

21. Mandel P, Kretschmer A, Chandrasekar T, et al. The effect of BMI on clinicopathologic and functional outcomes after open radical prostatectomy. Urol Oncol 2014;32:297-302. http://dx.doi.org/10.1016/i. urolonc.2013.09.005

Correspondence: Dr. Bulent Altay, Department of Urology, Istanbul Medipol University, Medipol Hastanesi, Kosuyolu, Kadikoy, Istanbul, 34718, Turkey; baltay@medipol.edu.tr 